\title{
A nagyérvasculitisek képalkotó vizsgálatának lehetőségei és azok jelentősége
}

\author{
Kolossváry Endre dr. ${ }^{1}$ - Balázs György dr. ${ }^{2}$. Dósa Edit dr. ${ }^{3}$ \\ Moravszki Mónika dr. ${ }^{4}$ - Járai Zoltán dr. ${ }^{5,6}$. Farkas Katalin dr. ${ }^{1,6}$ \\ ${ }^{1}$ Szent Imre Egyetemi Oktatókórház, Angiológia, Budapest \\ ${ }^{2}$ Heim Pál Országos Gyermekgyógyászati Intézet, Gyermek MR és CT Diagnosztikai Központ, Budapest \\ ${ }^{3}$ Semmelweis Egyetem, Általános Orvostudományi Kar, Városmajori Szív- és Érgyógyászati Klinika, \\ Intervenciós Radiológia Tanszék, Budapest \\ ${ }^{4}$ Magyar Honvédség Egészségügyi Központ, Nukleáris Medicina Osztály, Budapest \\ ${ }^{5}$ Szent Imre Egyetemi Oktatókórház, Kardiológia, Budapest \\ ${ }^{6}$ Semmelweis Egyetem, Általános Orvostudományi Kar, Angiológiai Tanszéki Csoport, Budapest
}

\begin{abstract}
A Chapel Hill-i Konszenzuskonferencia által megfogalmazott beosztás szerint az óriássejtes arteritis és a Takayasuarteritis tartozik a nagyérvasculitisek csoportjába. E kórállapotok felismerése döntően a klinikai kép értékelésén, valamint a különböző vascularis képalkotó módszerek alkalmazásán alapul. Az utóbbi lehetőséggel kapcsolatban az elmúlt években jelentős technológiai fejlődés figyelhető meg, amely már nemcsak a diagnózis felállítását, hanem a betegség kiterjedtségének és az érfali gyulladás fokának a megítélését is lehetôvé teszi. Ezenfelül az érfali gyulladás későbbi szövődményeinek felismerése is lehetővé válik. Az ultrahang, a komputertomográfia és a mágnesesrezonancia-vizsgálat, valamint a pozitronemissziós tomográfia képviselik azokat a képalkotó modalitásokat, amelyek a bennük rejlő lehetőségek miatt elengedhetetlenek az érintett betegek felismeréséhez, valamint hatékony kezelésük és követésük tervezéséhez. Az ismeretek összefoglalása számos, az érintett betegek gondozásában potenciálisan érintett szakterület érdeklődésére tarthat számot.
\end{abstract}

Orv Hetil. 2020; 161(23): 939-950.

Kulcsszavak: nagyérvasculitis, vascularis képalkotás

\section{The potentials and importance of imaging in large-vessel vasculitis}

According to the nomenclature of the Chapel Hill Consensus Conference, giant-cell arteritis and Takayasu's arteritis belong to the group of large-vessel vasculitis. Recognition of these diseases is primarily based on the clinical assessment and the use of various vascular imaging modalities. With regard to the latter one, significant technological advances have been observed in recent years, which allow not only to make a diagnosis but also to evaluate the extent of the disease and the degree of vascular inflammation. In addition, subsequent complications of vascular inflammation can be examined. Ultrasound, computed tomography, magnetic resonance imaging, and positron-emission tomography represent imaging modalities that are essential for recognizing affected patients and planning effective treatment and follow-up. The review of this topic may be of interest to a number of medical specialties that are potentially involved in the care of these patients.

Keywords: large-vessel vasculitis, vascular imaging

Kolossváry E, Balázs Gy, Dósa E, Moravszki M, Járai Z, Farkas K. [The potentials and importance of imaging in large-vessel vasculitis]. Orv Hetil. 2020; 161(23): 939-950.

(Beérkezett: 2020. február 1.; elfogadva: 2020. február 28.) 


\section{Rövidítések}

${ }^{18} \mathrm{~F}$-FDG = $\left({ }^{18} \mathrm{~F}\right.$-fluorodeoxyglucose $){ }^{18} \mathrm{~F}$-fluor-dezoxi-glükóz; ACR $=($ American College of Rheumatology $)$ Amerikai Reumatológiai Kollégium; ACS = (arteritis composite score) arteritis összetett pontszám; CARDS $=($ combined arteritis damage score) kombinált arteritiskárosodási pontszám; $\mathrm{CHCC}=$ (Chapel Hill Consensus Conference) Chapel Hill-i Konszenzuskonferencia; $\mathrm{CPR}=($ curved planar reformation $)$ kanyarodó ábrázolás; $\mathrm{CRP}=\mathrm{C}$-reaktív protein; $\mathrm{CT}=($ computed tomography) számítógépes tomográfia; CTA = CT-angiográfia; DCVAS $=($ Diagnostic and Classification Criteria in Vasculitis Study) diagnosztikai és osztályozási kritériumok a vasculitis vizsgálatában; DSA = digitális szubtrakciós angiográfia; EULAR $=($ European League Against Rheumatism $)$ Európai Reumaellenes Liga; GCA = (giant-cell arteritis $)$ óriássejtes arteritis; IFN $\gamma=$ interferon- $\gamma$; IL = interleukin; IMT = (intima-media thickness) intima-media vastagság; $\mathrm{MPR}=$ (multiplanar reformation) többsíkú reformált; $\mathrm{MR}$ = mágneses rezonancia; $\mathrm{PET}=$ pozitronemissziós tomográfia $; \mathrm{PET} / \mathrm{CT}=$ pozitronemissziós tomográfiával kombinált számítógépes tomográfia; PMR = polymyalgia rheumatica; SUVaverage $=($ averaged stan dardized uptake value) átlagos standardizált felvételi érték; SUVmax $=$ (maximum standardized uptake value) maximalizált standardizált felvételi érték; TA = Takayasu-arteritis; TABUL $=$ Temporal Artery Biopsy vs ULtrasound in Diagnosis of GCA; TBR = target-to-background ratio; $\mathrm{Th}=(\mathrm{T}$ helper) segítő T; TSPO = transzlokátor protein; TVS = (total vascular score) teljes vascularispontszám; $\mathrm{UH}=$ ultrahang; $\mathrm{VR}$ = (volume rendering) volumenábrázolás

A primer vasculitisek rendkívül heterogén betegségcsoportot alkotnak; közös jellemzőjük az érfali gyulladás megjelenése és a következményes adott érellátási terület keringészavara, amelyet szisztémás gyulladásos reakció kísér. A későbbiekben a gyulladás mérséklődését követően az adott érfal strukturális és funkcionális változása (remodelling) kapcsán érszúkület/érelzáródás vagy értágulat alakulhat ki. A Chapel Hill-i Konszenzuskonferencia (CHCC) a primer vasculitisek rendszerbe foglalását tûzte ki célul. A besorolásnál az érintett erek méretét vették alapul. Ebben a rendszerben a nagyérvasculitisek közé két betegség került: az óriássejtes arteritis (GCA) és a Takayasu-arteritis (TA) [1]. E két betegség a vascularis képalkotás fejlődésével egyre gyakrabban kerül felismerésre. A képalkotás jelentősége nem korlátozódik a nagyérvasculitis diagnosztikájára. A betegség kiterjedtsége, az érfali gyulladás monitorozása, az alkalmazott immunszuppresszív terápia hatékonyságának megítélése, az esetlegesen szükségessé váló invazív (érsebészeti, endovascularis) beavatkozások optimális időzítése, valamint a késői, prognózist meghatározó eltérések (érelzáródás, értágulat) felismerése mind olyan terület, amelynél a különböző radiológiai modalitások pótolhatatlan segítséget nyújthatnak [2-5].

\section{A nagyérvasculitisek diagnózisának nehézségei}

Korábban a diagnosztikus törekvés mind az óriássejtes arteritis, mind a Takayasu-arteritis esetén az Amerikai Reumatológiai Kollégium (ACR) kritériumrendszerén alapult. Ebben a rendszerben bizonyos betegjellemzők, a klinikai tünetek, a labor-, a szövettani és a képalkotó vizsgálati eltérések együttese alapozta meg a diagnózist. A kritériumrendszer kidolgozásakor egy 1982 és 1987 között, 1020 beteg bevonásával végzett multicentrikus vizsgálat adatainak elemzését végezték el [6,7]. Az azóta eltelt idő alatt világossá vált, hogy ennek a rendszernek a diagnosztikus törekvés során való alkalmazása több szempontból is korlátozott értékú.

Az első probléma, hogy a rendszert nem a vasculitisek diagnosztikájának segítésére dolgozták ki, hanem a különböző vasculitisek egymástól történő elkülönítése, klasszifikációja szolgált a tanulmány céljául (az alapul vett betegpopulációban a bevonást megelőző két évben ugyanis már igazolták a vasculitis tényét). Ebben az értelemben egy klasszifikációs rendszerként szolgáló kritériumrendszer érzékenységi mutatói (szenzitivitás, specificitás) diagnosztikus eszközként használva törvényszerűen csökkent értékúek [8].

A következő probléma, amely a klasszifikációs rendszer alkalmazásával függ össze, hogy az csak egy adott manifesztáció felismerését teszi lehetôvé. Ezzel szemben az elmúlt években világossá vált, hogy mind az óriássejtes arteritis, mind a Takayasu-betegség széles spektrumot mutató, heterogén kórforma. Ez az óriássejtes arteritis esetén a klasszifikációs kritériumrendszerben leírt cranialis formától (az arteria carotis externa ellátási területe) a kizárólag szisztémás gyulladást okozó larvált megjelenésen át az extracranialis kórformákig (az aorta, a végtagi erek érintettsége) terjed úgy, hogy idetartozónak gondolják a szimmetrikus vállövi és/vagy medencefájdalom képében jelentkező, synovialis gyulladással járó polymyalgia rheumaticát (PMR-t) is. Az utóbbi esetben, bár artériás keringészavar nem észlelhető, a későbbiekben tárgyalt PET-vizsgálatok tanúsága szerint az aorta fokozott nyomjelzőfelvétele mutatható ki, ami lappangó érfali gyulladásra utal [9]. Emellett az is felmerült, hogy külön entitást képviselnek azok a formák, amelyek nem érszúküulet, -elzáródás, hanem érdilatáció, aneurizma képződésével járnak [10]. Ezen megjelenési formák elkülönítésének nemcsak az az alapja, hogy eltérő érterületi érintettség jellemzi őket, hanem a kialakulásukért felelôs gyulladásos citokinek mintázata is eltér némileg egymástól [11]. Az eddigiekben tárgyalt fenotípusok gyakran egymással átfedésben, egyidejúleg is felismerhető́k [9]. Takayasu-arteritis esetén hasonlóan - attól függően, hogy az aorta melyik szakasza, illetve melyik aortaág érintett - az angiográfiás kép alapján hat típus különíthető el [12]. A korábbi klasszifikációs rendszer 
hiányosságait felismerve 2010-ben nemzetközi, multicentrikus epidemiológiai vizsgálat indult az Amerikai Reumatológiai Társaság (ACR), valamint az Európai Reumaellenes Liga (EULAR) támogatásával, amely a primer vasculitisek diagnosztikus és frissített klasszifikációs rendszerének kifejlesztését tüzte ki célul (Diagnostic and Classification Criteria in Vasculitis Study - DCVAS) [13]. Az új klasszifikációs és diagnosztikus rendszerre történő ajánlásokban a nagyérvasculitisek esetén kiemelt jelentőségú kérdésként jelenik meg a képalkotó eljárások alkalmazhatósága [14].

\section{A képalkotó eljárások lehetôségei a nagyérvasculitisek diagnosztikájában}

A nagyérvasculitisek diagnosztikájában a legtöbb tapasztalat az ultrahang (UH)-technológiával kapcsolatban áll rendelkezésre. Az UH-t először az arteria temporalis superficialis falában zajló gyulladásos folyamatok megítélésére használták. Az óriássejtes arteritisre specifikus "halo"-jelet 1995-ben Schmidt és mtsai írták le [15]. A szövettanilag érfali ödémának és a tunica media gyulladásos sejtek általi infiltrációjának megfeleltethető „halo"-jel az UH-felvételeken az érfal koncentrikus, echoszegény kiszélesedésének a képében ábrázolódik. $\mathrm{Az}$ érlumen diffúz beszúkülése rendszerint mind a keresztmetszeti, mind a hosszmetszeti színkódolt felvételeken jól látható.

$\mathrm{Az}$ arteria temporalis bőrfelszín alatt közvetlenül futó fóágának átlagos átmérője 1,5-1,9 mm, elsődleges mellékágainak (temporalis, parietalis) átmérője pedig 0,70,8 mm. A képalkotás B-módban 10-15 MHz-es, míg color-módban legalább $6 \mathrm{MHz}$-es lineáris transzducerrel történik. Deprimált áramlás esetén a power-Dopplertechnika is alkalmazható [16]. A „halo”-jel kimutatásakor ügyelni kell az erősítés (gain) megfelelő beállítására, mert szuboptimális erősítés mellett a „halo”-jel eltűnhet, vagy ún. pszeudo „halo”-jel alakulhat ki [17].

További pozitív jel az ún. kompressziós jel, amely azt jelenti, hogy a gyulladt érszakasz lumene transzducerrel nem teljesen nyomható össze [18]. Idővel - a gyulladás következményeként - az involvált artérián stenosis vagy occlusio jöhet létre. Mindezen eltérések közül a „halo”jel tekinthető a legspecifikusabb diagnosztikus kritériumnak [17]. További lehetőség a gyulladás okozta megnövekedett intima-media vastagságnak (IMT) a kimutatása. Az IMT normálértékének meghatározásával kapcsolatban az egyik, módszertanilag talán a legátfogóbb tanulmány mérési eredményeinek alapján az arteria temporalis superficialis fötörzsének az IMT-je $0,42 \mathrm{~mm}$, a frontalis mellékág IMT-je $0,34 \mathrm{~mm}$, a parietalis mellékág IMT-je 0,29 mm, az arteria facialis IMT-je pedig 0,37 $\mathrm{mm}[19]$.

Az UH érzékenységét és fajlagosságát más eljárásokkal (arteria temporalis superficialis biopsziával, magas felbontású MR-vizsgálattal, klinikai diagnosztikus elemzésekkel) való összevetésben értékelő tanulmányok szerint arteritises betegeknél az UH szenzitivitása 70-96\%-os, míg specificitása 90-100\%-os [20]. Az UH-vizsgálat diagnosztikus alkalmazásával kapcsolatos dilemmákat jól érzékelteti az eddigiekben legátfogóbb prospektív vizsgálat (TABUL): ebbe 381 olyan beteget vontak be, akinél a klinikai kép alapján felmerült az óriássejtes arteritis lehetősége. A betegeknél arteria temporalis biopszia és UH-vizsgálat is történt. A 6 hónapos utánkövetés során a betegek 67\%-ában igazolódott óriássejtes arteritis. Az UH-vizsgálat a szövettani vizsgálattal összehasonlítva magasabb szenzitivitást ( $54 \%$ vs. $39 \%$ ) és alacsonyabb specificitást ( $81 \%$ vs. $100 \%$ ) mutatott. Az UH-vizsgálat szenzitivitását befolyásolta, hogy ki végezte a vizsgálatot. Az esetek 7,4\%-ában a vizsgáló és a szakértői ellenőrzést végző csoport eltérő véleménye alapján a betegeket reklasszifikálták. Az UH szenzitivitása csökkent annak függvényében is, hogy a vizsgálat hány napos kortikoszteoridterápiát követően történt. Két nap elteltével a szenzitivitás már csak 47\%-os volt. A betegek 30\%-ánál az arteria temporalis superficialis biopszia és az UH-vizsgálat eltérô eredményre jutott. A betegeknek a beválasztást 2 héttel követően történő klinikai értékelése növelte a szenzitivitást és a specificitást. Az UH-vizsgálat alkalmazása a szövettani vizsgálatot $43 \%$-ban tette elkerülhetővé. Abban az esetben, ha a klinikai tünetek és az UHvagy a szövettani vizsgálat együttesen került értékelésre, az UH-vizsgálat szenzitivitása és specificitása 93\%-os és 77\%-os, míg a szövettani vizsgálaté $91 \%$-os és $81 \%$-os volt. Ez a megfigyelés a kombinált diagnosztikai megközelítést támogatja [21]. Összefoglalva tehát sem a szövettani vizsgálat, sem az UH-vizsgálat nem tekinthető „arany standardnak”. A kettő ötvözésével, illetve a beteg klinikumának figyelembevételével a diagnosztikus érzékenységi mutatók javíthatók. Az egyik vagy a másik eljárás negativitása nem zárja ki az óriássejtes arteritis fennállását [21].

A TABUL-vizsgálat további megfigyelése volt, hogy ha az UH-vizsgálatot kiterjesztették az arteria axillaris vizsgálatára, a betegek 13,9\%-ában volt kimutatható a „halo”-jel. Azon betegek számaránya, akiknél az eltérés izoláltnak mutatkozott, 2,4\% volt [21]. Más tanulmányok tanúsága szerint az óriássejtes arteritis extracranialis manifesztációja esetén a leggyakrabban az arteria axillaris érintettsége mutatható ki (29-50\%) (1.ábra). Ez a tény, valamint az, hogy az atherosclerosis ritkán érinti ezt az UH-transzducerrel könnyedén megközelíthető területet, az arteria axillaris UH-vizsgálatának fontosságát hangsúlyozza. Normál esetben ezen az érterületen az IMT nem haladja meg a 0,6 mm-es vastagságot. Kórosnak az $1 \mathrm{~mm}$ feletti IMT-értéket tekintik [19]. Az arteria temporalis superficialis és az arteria axillaris együttes elemzésével a diagnosztikus hatékonyság növelhető [22]. Alacsonyabb gyakorisággal az arteria subclavia és az arteria brachialis proximalis érintettségéról is beszámolnak [23, 24]. Más érterületi lokalizációról kevesebb adat áll rendelkezésre. Ezek alapján az arteria carotis communis 6-25\%-ban, az arteria vertebralis 5-17\%-ban, 

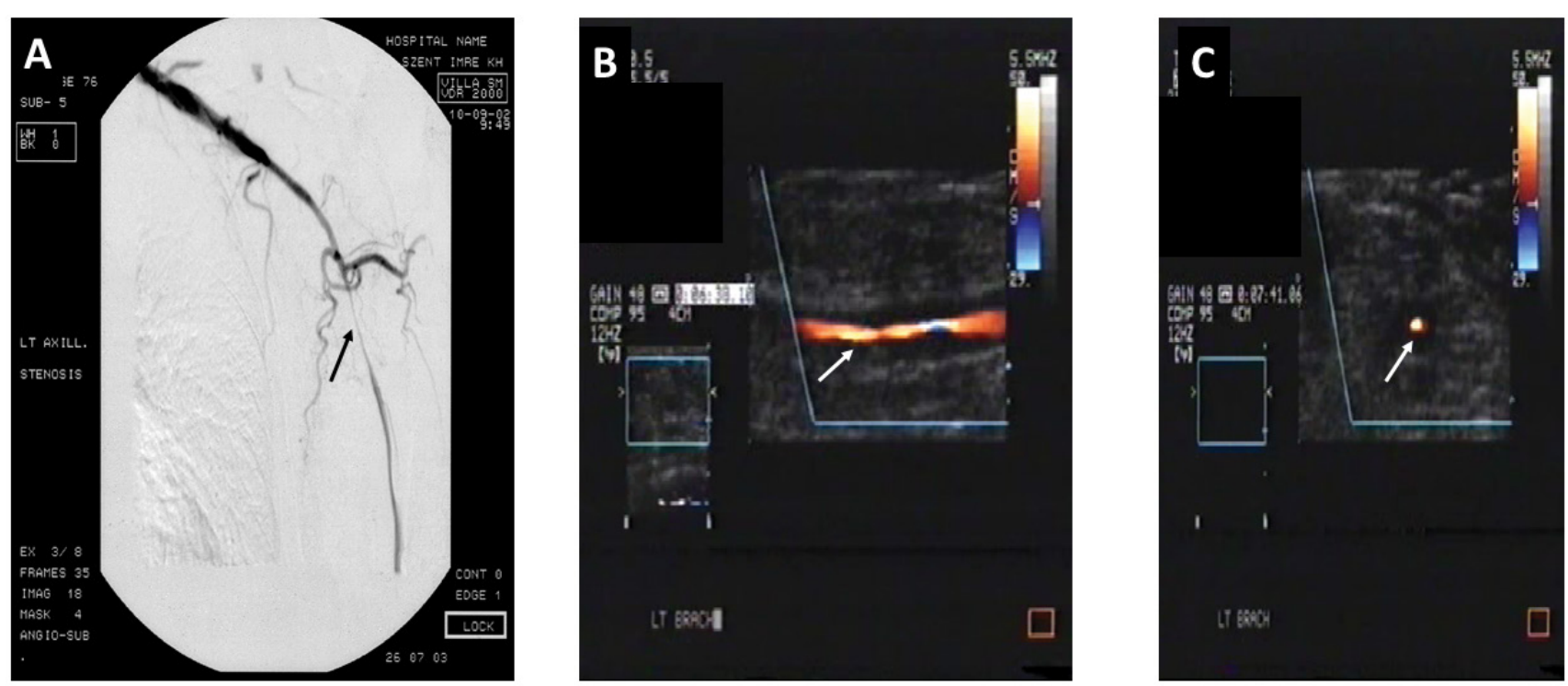

1. ábra

A „halo”-jel megjelenése a color duplex UH-képen óriássejtes arteritis nagyér-manifesztációja esetén (Kolossváry Endre anyagából). A: Arteria brachialis hosszanti, nem atheroscleroticus szúkületének DSA-képe. B: Az érintett arteria brachialis szakasz hosszmetszeti color duplex UH-képe, echószegény hosszanti lumenredukció („halo”-jel). C: Ugyanazon szúkület keresztmetszeti color duplex UH-képe

DSA = digitális szubtrakciós angiográfia $; \mathrm{UH}=$ ultrahang

az alsó végtagi artériák pedig 24\%-ban voltak érintettek. Néhány esetben transoesophagealis UH-vizsgálattal a felszálló aorta falának megvastagodása volt látható. A hasi aortaszakaszra vonatkozó adatok bizonytalanok [20].

Óriássejtes arteritis klinikai gyanúja esetén egy olyan betegellátási modellt javasolnak (fast-track clinics), amely az UH-vizsgálatot sürgősséggel elérhetővé teszi. Ennek célja részben az esetleges akut szövődmény (vakság) elkerülése, részben pedig annak megelőzése, hogy az időközben elkezdett immunszuppresszió mellett a képalkotás értékelése ne korlátozódjon. Ehhez az ez irányú széles körü képzés kialakítása szükséges [25].

$\mathrm{Az}$ óriássejtes arteritishez hasonlóan a Takayasu-arteritis diagnosztikájában is alkalmazható az UH-vizsgálat. Ennek alapja szintén a körkörös fali megvastagodás kimutatása. Az érfali gyulladást közepes echogenitású eltérésként írták le, amelyet „macaroni”-jelnek hívnak. Az érintett érterületi mintázat különbözik az óriássejtes arteritisétől. Jellemző a kétoldali arteria carotis communis, valamint az arteria subclavia érintettsége. Az utóbbi nemritkán a proximalis érszakasz jelentôs szúkületéhez vagy elzáródásához vezet. A mellkasi aorta érintettsége gyakori, emellett leírták az arteria renalis proximalisnak a magas vérnyomáshoz vezetô szúkületét is [20]. A betegség, az óriássejtes arteritisszel összevetve, jellemzően a proximalis érterületeket érinti, ami az UH-vizsgálatok korlátját jelenti a Takayasu-arteritis diagnosztikájában.

$\mathrm{Az}$ adatok nem egységesek abban a vonatkozásban, hogy az elkezdett kortikoszteroidkezelés milyen mértékben csökkenti az UH-vizsgálatok szenzitivitását. Egyes tanulmányok már néhány napos kezelést követően csökkent kimutathatóságról számolnak be cranialis megjele- nés esetén, míg más közlemények szerint az UH-eltérés akár hónapokon át kimutatható, fóleg a nagyereket érintô manifesztáció fennálltakor [20].

A számítógépes tomográfiás (CT-) vizsgálatok - az óriássejtes arteritis cranialis formájától eltekintve - a vasculitisek nagyér-manifesztációjának gyanúja esetén hatékony diagnosztikus lehetőséget képviselnek.

A CT-felvételeket vékony metszetvastagsággal (0,6-1 $\mathrm{mm})$ kell készíteni. A klasszikus, atheroscleroticus betegeknél megszokott CT-protokolltól eltéróen vénás fázisú felvétel készítése is szükséges, 50 szekundummal az artériás fázist követően. E célból magasabb kontrasztanyagdózisra $(2 \mathrm{ml} / \mathrm{tskg})$ van szükség, a pusztán artériás fázisú CTA-méréssel összehasonlítva. A CT-vizsgálat során a diagnózis jellemzően a koncentrikus érfali megvastagodás kimutatásán alapul. A natív CT-képeken ez magas denzitást mutathat, emellett az érfalban kalcifikáció jelentkezhet, amely az atheroscleroticus érelváltozásokkal ellentétben gyakran transmuralis. Kontrasztanyag alkalmazását követően az artériás fázisban az érfal a lumenhez képest hypodens lesz, míg vénás fázisban jellemző jel a magas és alacsony denzitású kettős gyưrú megjelenése. Ennek hátterében a megduzzadt intimaréteg (belső gyưrü), illetve a gyulladásos media- és adventitiaréteg (külső gyưrû) elkülönülését valószínúsítik [12, 26] (2. ábra). Az érfali struktúra változásai mellett a CTvizsgálat alkalmas az érlumen változásainak megjelenítésére is. A szúkületek kimutatása elsődleges a diagnózis felállításakor, emellett érelzáródások, valamint aneurizmatikus tágulatok megjelenése is jellemzó lehet. Az esetenként bonyolult anatómiai mintázat ábrázolását többsíkú (MPR - multiplanar reformation) és kanyarodó (CPR - curved planar reformation) másodlagos refor- 

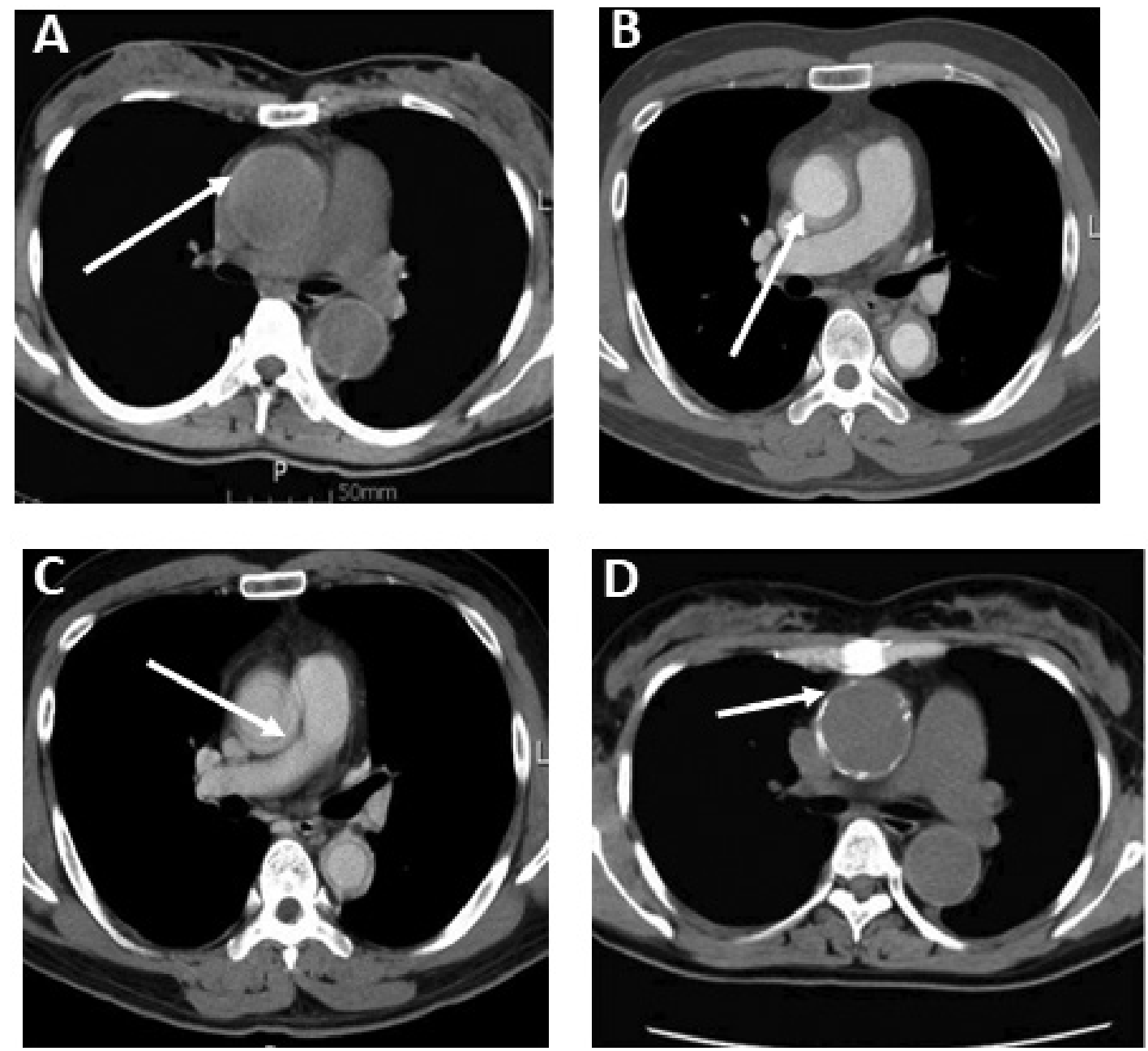

2. ábra

Jellemző CT-eltérések Takayasu-arteritisben (a Korean Journal of Radiology hozzájárulásával [26]). A: Natív felvételen az aorta felszálló szakaszán látható érfali megvastagodás. B: Kontrasztanyag adását követő érfali halmozás az artériás fázisban. C: Vénás fázisban jelentkező érfali kettős kontúr megjelenése. D: Pontszerű kalcifikáció megjelenése a betegség későbbi fázisában

CT = számítógépes tomográfia

mált felvételek segíthetik, valamint 3 dimenziós volumenábrázolás (VR - volume rendering) is alkalmazható. A primer axiális és a másodlagos reformált felvételek együttes analízise alapján a nemritkán bonyolult lefutási és kalibereltérések, valamint a kollaterális keringés jelei nagy biztonsággal azonosíthatók $[12,26]$.

A fenti technikai szempontok figyelembevételével az óriássejtes arteritis extracranialis formája esetén egy vizsgálatban, a klinikai diagnózist alapul véve, a CT-vizsgálat 73\%-os szenzitivitást és 78\%-os specificitást mutatott. Takayasu-arteritis esetén egy tanulmány 100\%-os szenzitivitásról és specificitásról számolt be a konvencionális angiográfiás vizsgálattal való összehasonlításban [27].

A nagyérvasculitisek felismerésekor az MR-vizsgálatok úgyszintén ígéretes alternatívát jelentenek. A vizsgálatok technikai igényeit tekintve az intracranialis, illetve a felületes extracranialis vizsgálatokat célszerü 3 T-s készülékkel és legalább 8 csatornás feji tekerccsel végezni. Elnyújtott gadolíniumbolus beadása esetén, több lépésben, akár teljestest-ábrázolásra is lehetőség nyílik. Így a sup- raaorticus artériáktól egészen az alsó végtagi artériás rendszerig DSA-szerû megjelenítésre van módunk a lumen vonatkozásában. Ennek kiegészítéseként az érfali gyulladás kimutatására részben az ödémára érzékeny, zsírelnyomásos T2-súlyozott mérési mód, részben pedig a kontrasztanyagadást követő zsírelnyomásos Tl-súlyozott mérés alkalmas (3. ábra). A keringés dinamikája is megítélhető a többfázisú, ún. 'time-resolved' MR-angiográfiás módszerrel.

Óriássejtes arteritis gyanúja esetén az MR-vizsgálatok során vasculitisre utaló direkt jelnek tekintik az érfal megvastagodását, valamint a fokozott érfali kontraszthalmozódást. Az arteria temporalis vizsgálatakor e két tényezőt alapul véve 4 fokozatú skálát dolgoztak ki (0-3), amelynek értékelése során a 2 -es, illetve a 3-as érték utal érfali gyulladásra. A $600 \mu \mathrm{m}$-es falvastagságot tekintették diagnosztikus határértéknek [28]. Egy metaanalízis szerint (6 vizsgálat) ez a diagnosztikus megközelítés a klinikai tünetek és/vagy az arteria temporalis biopszia eredményével összevetve 73\%-os szenzitivitást (57-85\%-os) 

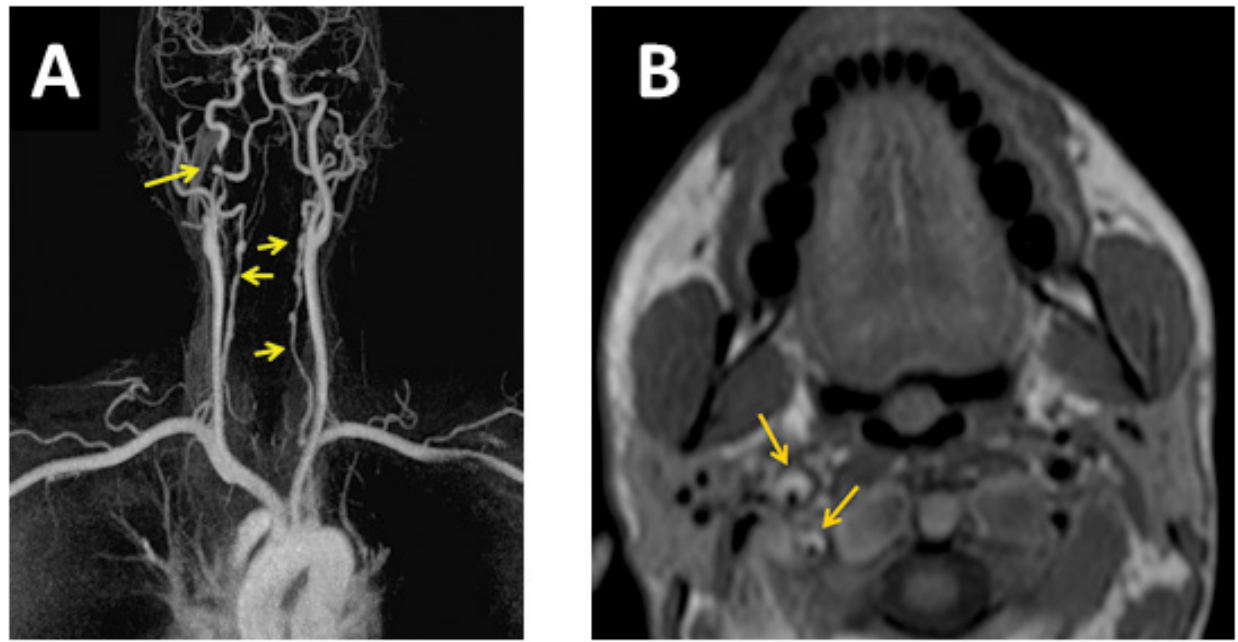

3. ábra

Jellemző MR-eltérések Takayasu-arteritisben (Kolosssváry Endre anyagából). A: Jobb oldali arteria carotis interna subocclusiv szúkülete, mindkét olda li arteria vertebralisok többszörös szúkületei (nvíllal jelölve) (3D MIP rekonstrukciós kontrasztos MR-kép, koronális sík). B: Fokozott kontraszthalmozást mutató érfali vastagodás a jobb oldali arteria carotis interna és az arteria vertebralis területén (nyíllal jelölve) (Tl-súlyozott MR-kép, axiális sík)

MIP = legnagyobb intenzitás kivetítése; $M R$ = mágneses rezonancia

és $88 \%$-os specificitást (81-92\%-os) mutatott. Ha összehasonlítási alapként csak a biopszián alapuló eredményeket tekintették, a szenzitivitás 93\%-os (89-96\%-os), a specificitás pedig $81 \%$-os (73-87\%-os) volt [27]. Hozzá kell tenni, hogy az MR-vizsgálat az összes vizsgálatban a glükokortikoidterápia elkezdése után történt, és a vizsgálatok arra utalnak, hogy a vizsgálat érzékenysége az immunszuppresszió időtartamával csökken. Mindazonáltal ha a klinikai gyanú megalapozza, a terápia nem késleltethető az MR-vizsgálat időpontja miatt [29]. Az óriássejtes arteritis extracranialis manifesztációjával kapcsolatban nem ismeretesek MR-vizsgálaton alapuló diagnosztikus vizsgálatok. Takayasu-arteritisben az invazív digitális szubtrakciós angiográfiával (DSA) összevetve három vizsgálat összevont eredménye szerint az MR- vizsgálat szenzitivitása 79\%-os (53-93\%-os), specificitása pedig 97\%-os (95-99\%-os) volt. A szenzitivitás MR-angiográfia esetén magasabb, 92\%-os (88-95\%-os) volt [30]. Ezek a vizsgálatok relatíve kevés beteg bevonásával történtek. Az MR- és a DSA-vizsgálatok között hoszszabb idő telt el.

A nagyérvasculitisek diagnosztikájának további lehetséges eszköze a nukleáris medicina képalkotó vizsgálóeljárásai közül is a pozitronemissziós tomográfia (PET). A PET-vizsgálat során nyomjelzőként alkalmazott cukoranalóg, a ${ }^{18}$ F-fluor-dezoxi-glükóz ( $\left.{ }^{18} \mathrm{~F}-\mathrm{FDG}\right)$ a fokozott metabolikus aktivitást mutató sejtekben dúsul (4. ábra). Nem ismert, hogy vasculitis esetén a ${ }^{18}$ F-FDG csak az érfalat infiltráló gyulladásos sejtekben vagy az érfali szerkezetet kialakító stromasejtekben is halmozódik-e.
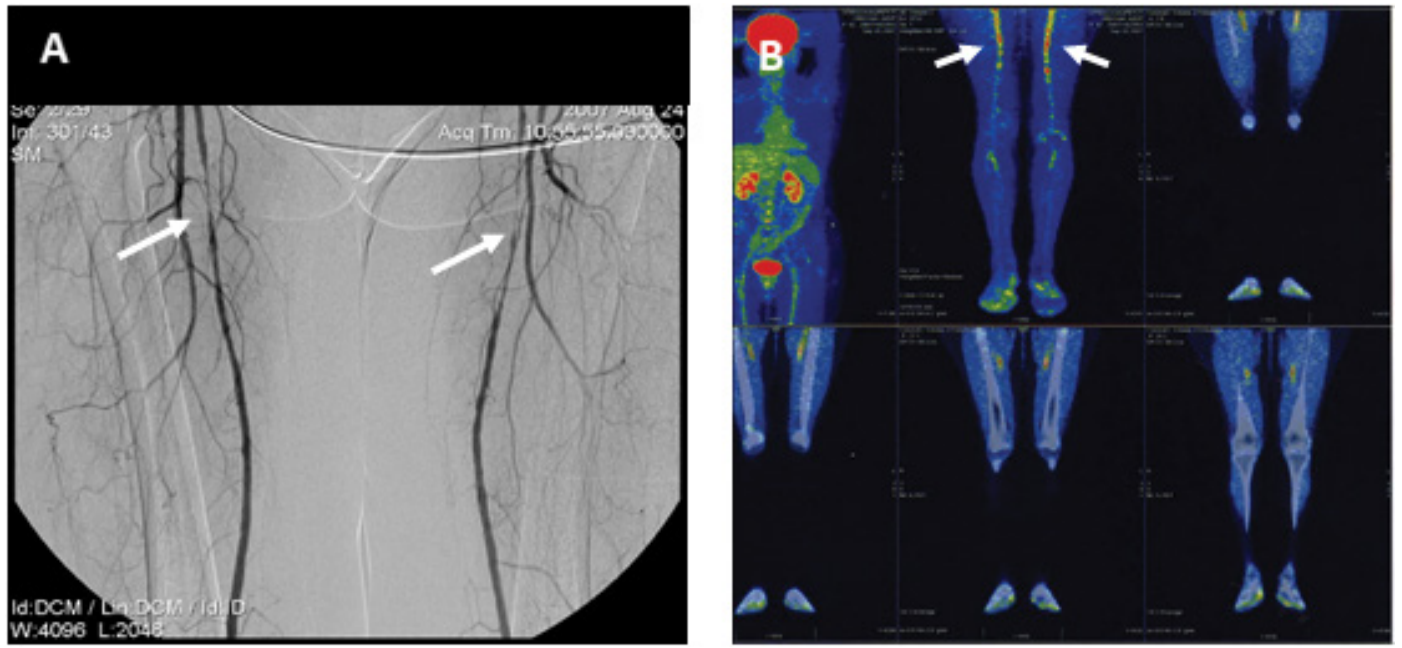

4. ábra

Jellemző PET-eltérések óriássejtes arteritis nagyér-manifesztációjában (Járai Zoltán anyagából). A: Mindkét oldali arteria femoralis superficialis többszörös szúkületének angiográfiás képe (DSA). B: A többszörösen szúkült arteria femoralis superficialis fokozott nyomjelzö ( $\left.{ }^{18} \mathrm{~F}-\mathrm{FDG}\right)$-felvétele

${ }^{18} \mathrm{~F}-\mathrm{FDG}={ }^{18} \mathrm{~F}$-fluor-dezoxi-glükóz; DSA = digitális szubtrakciós angiográfia $;$ PET = pozitronemissziós tomográfia 
A gyulladás kimutatásának korlátot szab az érátmérő: a módszer csak a 4 mm-nél nagyobb átmérőjű erek vizualizálására alkalmas. A képfelbontás korlátja, valamint az agyi fokozott cukorfelvétel miatt az arteria temporalisra korlátozódó GCA esetén a PET-vizsgálat nem alkalmazható.

A vizsgálat elvégzése előtt számos technikai szempont figyelembevétele szükséges. Standardizált körülmények szükségesek. Fontos szempont, hogy a glükokortikoidok szisztémás alkalmazása csökkenti az érfali ${ }^{18} \mathrm{~F}-\mathrm{FDG}$-felvételt, így a vizsgálat szenzitivitása csökkenhet. A vizsgálatok tanúsága szerint ez a tényező 3 napon belül nem számottevő, ezt követően azonban a nyomjelző felvétele szignifikánsan csökken. Ha az immunszuppresszív terápiát már el kellett kezdeni, elvben felvethető e terápia időleges leállításának lehetősége, ám ez egyedi elbírálást igényel. Nem tisztázott egyértelmúen, hogy a ${ }^{18} \mathrm{~F}-\mathrm{FDG}$ iv. beadása és a képalkotás között mennyi idő teljen el. Feltételezhető, hogy a minimálisan javasolt, 60 percnél hosszabb várakozás kontrasztosabb képalkotást tenne lehetővé [31], az eddigi vizsgálatokhoz képest történő eltérés azonban nem tenné összehasonlíthatóvá a vizsgálatot az eddigi tapasztalatokkal. Ennek megfelelően 60 perces inkubációs idő ajánlott a nyomjelző beadása és a képalkotás között. A képalkotás során teljestest-ábrázolás (fejtől térdig, esetleg lábfejig) ajánlott.

A képalkotást követő képértékelés során egy vizuális gradusrendszer alkalmazását javasolják (Meller-skála). $\mathrm{Ez} 4$ fokozat elkülönítését jelenti: 0 . $\left({ }^{18} \mathrm{~F}-\mathrm{FDG}-\right.$ felvétel $\leq$ mediastinum $) ; 1$. alacsony felvétel $\left({ }^{18} \mathrm{~F}-\mathrm{FDG}-\right.$ felvétel $<$ máj); 2 . közepes felvétel $\left({ }^{18} \mathrm{~F}-\mathrm{FDG}\right.$-felvétel $=$ máj); 3. magas felvétel ( ${ }^{18} \mathrm{~F}-\mathrm{FDG}$-felvétel>máj). Ebben a rendszerben a 2 . fokozat felveti, a 3 . fokozat pedig megerósíti a nagyérvasculitis diagnózisát. Miután az óriássejtes arteritis gyakran jár együtt PMR-rel, az esetlegesen érintett ízületi régiók hasonló gradusokra történő beosztása is szükséges. Az atheroscleroticus érelváltozások is halmozhatják a nyomjelzőként alkalmazott ${ }^{18} \mathrm{~F}-\mathrm{FDG}$ - $\mathrm{t}$. $\mathrm{Az}$ elkülönítésben segíthet az eltérő érterületi érintettség, a nagyérvasculitisekre jellemző, hosszú érszakaszon kimutatható lineáris mintázat, szemben az atheroscleroticus eredetű érelváltozások szabálytalan, foltos megjelenésével. Külön kiemelik, hogy az alsó végtagi artériák ${ }^{18}$ F-FDG-felvétele kevésbé specifikus nagyérvasculitisre, így izolált megjelenése óvatosan értelmezendő. Mindazonáltal ha az alsó végtagi manifesztáció a fenti gradusrendszerben 3-as értéket mutat, úgy az nagyérvasculitist valószínüsít.

A vizuális megítélés mellett léteznek olyan szemikvantitatív módszerek is, amelyek alkalmazhatósága jelenleg nem a klinikai gyakorlat, hanem inkább a kutatás tárgyát képezik.

A maximalizált vagy az átlagos standardizált felvételi érték (maximum or averaged standardized uptake value, SUVmax, SUVaverage) meghatározása során a nyomjelző érfalban való felvételének kvantitatív meghatározása történik. Problémát jelent, hogy nem ismeretes olyan határérték, amely biztonsággal elkülönítené a nagyérvas- culitisben szenvedő betegeket a kontrollszemélyektől, így a módszer diagnózis felállítására nem alkalmas. Ígéretesebb az a megoldás, hogy az érfali SUV-értékeket egy referenciaszerv (máj, tüdő, vénás vér) felvételi értékeihez hasonlítják (TBR - target-to-background ratio). Ennek a megközelítésnek az az előnye, hogy miután SUV-arányok kerülnek meghatározásra, mérsékelhető a beteg testsúlyával, az alkalmazott nyomjelző dózisával és a mérési időpont megválasztásával kapcsolatos bizonytalanság. Referenciaterületnek máj esetén a jobb lebenyt (a fóartériás, vénás keringéstől távolabb helyezkedik el), vénás vér esetén pedig a vena cava inferiort vagy a vena cava superiort szokták tekinteni.

Ami a PET-vizsgálatnak a nagyérvasculitis diagnosztikájában betöltött szerepét illeti, a szenzitivitás és a specifitás számos vizsgálat, valamint ezek metaanalízise alapján magas értéket mutat. Egy korábbi, óriássejtes arteritisre vonatkozó metaanalízis szerint a szenzitivitás $80 \%$-os, a specificitás pedig $89 \%$-os. Egy frissebb tanulmányban ugyanezen értékek óriássejtes arteritis esetén 90\%-osak, illetve 98\%-osak, Takayasu-arteritis esetén pedig 87\%-osak, illetve 73\%-osak voltak [27, 33].

A PET-vizsgálatok nagyérvasculitisekben való alkalmazhatóságát további fejlesztések támogathatják. A nem teljesen érfali gyulladásra specifikus, a glükózmetabolizmuson alapuló nyomjelzők mellett más, például a gyulladásban kulcsszerepet játszó makrofágokra specifikus nyomjelzők intenzív kutatás tárgyai. Nagyérvasculitisben már közöltek olyan klinikai tanulmányt, amelyben a ${ }^{18} \mathrm{~F}$ FDG helyett egy makrofágspecifikus fehérjéhez (transzlokátor proteinhez - TSPO-hoz) kötődő nyomjelzőt (C-PKl1195-öt) alkalmaztak. Ezenkívül számos más, egyéb területen már kipróbálás alatt lévő, makrofágspecifikus nyomjelző (membránreceptorok, intracelluláris molekulák) lehetséges szerepe is felmerül [32].

További fejlődést jelent a most már standardnak tekinthető PET-vizsgálatnak a CT- vagy MR-vizsgálattal történő kombinációja. Ezen vizsgálatok során a gyulladásra utaló nyomjelzőfelvétel mellett a szerkezeti változások is ábrázolhatók. A CT/MR vizsgálat együttes alkalmazása részben kiegészítő módon fokozza a diagnosztikus érzékenységet, részben pedig a későbbi szövődmények (érelzáródás, aneurizma kialakulása) kimutatását is segítheti $[14,33,34]$. Adott esetben (MR) a kombinált képalkotás a fiatal betegek sugárexpozícióját is csökkentheti [35].

\section{A képalkotó eljárások lehetőségei a nagyérvasculitisek kiterjedtségének, mintázatának vizsgálatára}

A nagyérvasculitisek kiterjedtségének, érterületi mintázatának képalkotó modalitásokkal történő vizsgálata több szempontból is jelentős. A diagnózis felállítását segítheti a panaszokat nem okozó, de képalkotó eljárásokkal igazolható érfali gyulladás kimutatása. A különböző 
érterületeken detektálható manifesztáció mintázata hozzájárul a differenciáldiagnózishoz, valamint a betegség aktivitásával is összefügg. Új fenotípusok felismerésére nyílik lehetőség. Az érfali gyulladás késői következményeinek (érelzáródás, aneurizmaképződés) ismerete a hatékony terápia kialakításához is hozzájárul. Mindezek alapján a különböző érterületi manifesztációk objektív leírása a klinikai vizsgálatokban alkalmazható végponttá válhat [36]. A CT- és MR-vizsgálatok lehetővé teszik a teljestest-szintű érterületi mintázat elemzését. Ennek során több érterületen rögzítik az arteritises érkárosodások (szúkület, elzáródás, aneurizma) tényét és azok morfológiai tulajdonságait (a laesiók hossza, a szúkületek mértéke). Ezekből az adatokból kombinált arteritiskárosodási score-rendszereket dolgoztak ki (combined arteritis damage score - CARDS [37], arteritis composite score ACS [38]). Hasonló, a teljes test érterületi érintettségét feltérképező rendszer fejlesztésére a PET-vizsgálat is lehetőséget ad. Ennek során standardizált maximális nyomjelzőfelvétel-érték kerül meghatározásra 7 érterületen, és ebből származtatják a teljes vascularispontszámot (TVS-t), amely egy 0-tól maximálisan 21-es értékig értelmezett pontrendszert eredményez [39]. A nagyérvasculitisek kiterjedtségének, mintázatának teljestestvizsgálatai további standardizálást, validálást és prospektív vizsgálatokban való elemzést igényelnek.

\section{A képalkotó eljárások jelentősége a nagyérvasculitisek aktivitásának megítélésében}

A képalkotó eljárások a diagnózis felállítása mellett potenciálisan alkalmazhatók a nagyérvasculitisek aktivitásának megítélésére és a betegség monitorozására is. A kérdés több szempontból is nagy jelentőségü. A nagyérvasculitisek immunpatomechanizmusának részben történő tisztázása mutatott rá, hogy a szisztémás gyulladás és az érfali gyulladás sejtes/molekuláris mechanizmusai különböznek egymástól. Az aktiválódás során a gyulladásért felelős Th-sejteknek két csoportja alakul ki. A Thl-sejtek a lokális környezetben található citokinek (IL12 és IL18) hatására aktiválódnak, és jellemzően IFN $\gamma$-t termelnek. Emellett szisztémás Th17-sejt-aktiváció (IL6, IL1 $\beta$ és IL2) is megfigyelhető, ami IL17-képződéshez vezet. A betegséget jellemző lokális és szisztémás tünetek kialakulásáért ez a két sejtvonal és az általuk termelt citokinek tehetők felelőssé. A két mechanizmus különbözik egymástól a glükokortikoidkezelésre adott válasz tekintetében. Míg a Th17-sejtvonalhoz köthető immunválasz (szisztémás) glükokortikoid adására mérséklődik, addig a döntően IFN $\gamma$-alapú Thl-válasz (lokális) relatíve érzéketlen a glükokortikoid adására, ami magyarázhatja a visszatérő klinikai relapsusokat. Ennek megfelelően a szisztémás gyulladást tükröző biomarkervizsgálatok (süllyedés, CRP) a betegség aktivitásának megítélésére korlátozottan alkalmazhatók.
Az érfali gyulladás megítélése nemcsak a relapsusok felismerése és a gyógyszeres immunszuppresszió hatékonyságának megítélése miatt fontos (5. ábra). Amenynyiben a gyulladás szövődményeként létrejövő szúkületek okozta ischaemia vagy az aneurizmaképződés szükségessé teszi, elkerülhetetlenné válik az érbeavatkozás. Ezen (érsebészeti, endovascularis) beavatkozások kivitelezésekor a szövődmények elkerülése végett törekedni kell az érfali gyulladás minél hatékonyabb csökkentésére.

Az UH-technológiával kapcsolatos eredmények szerint az immunszuppresszív terápia mérsékli a gyulladásra utaló UH-eltéréseket. Terápia hatására a „halo”-jel vastagsága csökken, echogenitása pedig fokozódik. Temporalis arteritis esetén akár éveken át megmaradhat az érfal mérsékelt megvastagodása. Axillaris arteritis esetén az érfal ödémás vastagodása hónapokon vagy akár éveken keresztül fennállhat. A későbbiekben az érfali ödémára jellemző „halo”-jel eltűnik, ami a betegség aktivitásának csökkenését jelezheti, az ezzel kapcsolatos adatok azonban jelenleg bizonytalanok, így klinikai ajánlás erre vonatkozóan nincs [17]. Az érfal vastagságát évente két alkalommal ellenőrizve, annak növekedése a betegség aktivitásának fokozódását jelezheti [16].

Az érfali gyulladás UH-val történő megítélését teheti lehetővé a kontrasztanyagos UH-vizsgálati technológia, amelynek során a vörösvérsejteknél kisebb mikrobuborékok kerülnek intravénás beadásra. Gyulladás esetén a mikrobuborékok a vasa vasorum felól megjelennek az érfal rétegeiben, ami az intima-media réteg neovascularisatiójának felel meg. Ennek mértéke szemikvantitív módon fokozatokra osztható. Nagyérvasculitisek esetén kimutatták, hogy a kontrasztanyagos UH-vizsgálattal ábrázolt intima-media neovascularisatio mértéke össze-

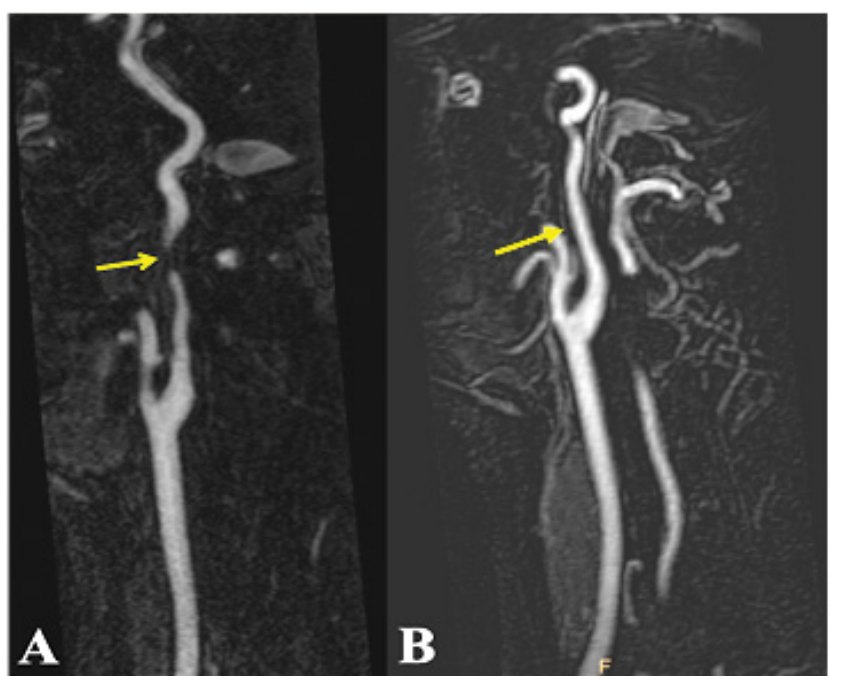

5. ábra

Takayasu-arteritis okozta jobb oldali arteria carotis interna szűkülete immunszuppresszív terápia előtt és 3 hónappal később (Kolossváry Endre anyagából). A: Jobb oldali arteria carotis interna szubtotális szúkülete terápia előtt (nyíllal jelölve). B: Jobb oldali arteria carotis interna szúkülete 3 hónapos kortikoszteroidterápia után 
függést mutat a PET-vizsgálatok során tapasztalt nyomjelzőfelvétellel, és korrelál a betegség klinikai tüneteken alapuló aktivitási pontszámértékével [40]. További lehetőség a vasculitis által okozott szúkülletek és a szúkület okozta áramlási spektrum változásainak több érterületen történő rögzítése. Az így nyert, ún. Kolkata-pontszám összefüggést mutatott a Takayasu-arteritis aktivitását jelző klinikai pontszámértékkel, valamint az immunszuppresszív terápia hatásával [41]. A betegség aktivitásának monitorozására az UH-vizsgálat nem általánosan javasolt. Azokban az esetekben, amikor a klinikai kép és a biomarker-vizsgálatok egybehangzóan relapsust vagy éppen tünetmentességet jeleznek, az UH-vizsgálat elvégzése nem jár járulékos haszonnal. Azokban az esetekben azonban, amikor ezek az adatok nem konzisztensek, az UH-vizsgálat segíthet [17]. Ennek elbírálása egyéni mérlegelést igényel.

Az MR-vizsgálatok során kimutatott késői érfali kontraszthalmozás mértéke a gyulladást tükrözheti vissza, ám a fibrosis is hasonló képet mutathat. Speciális intravascularis vagy „blood-pool” kontrasztanyag alkalmazásával kapcsolatosan jelent meg közlemény, amely szerint az ezzel a kontrasztanyaggal történt MR-vizsgálat a betegség gyulladásos aktivitását hűebben tükrözte vissza, mint a hagyományos, gadolíniumtartalmú kontrasztanyaggal készült vizsgálat [42]. Egy vizsgálatban a kontrasztanyagos MR-vizsgálat alkalmasnak tünt a biológiai terápia hatékonyságának monitorozására [43]. A CT-vizsgálattal igazolt érfali eltérések egyes vizsgálatok eredményei alapján 6-12 hónap alatt szűnnek meg. Ezzel ellentétben egy másik vizsgálat az aortafal-vastagodás megszünését 6 hónapos kezelés után csak 8,8\%-ban észlelte [34].

A betegség monitorozásában elvben ígéretesnek látszik a PET-vizsgálat alkalmazása. Az immunszuppresszív terápia indítását követően a PET-vizsgálat 10-14 nap alatt az érfali nyomjelző dúsulásának jelentős csökkenését mutatja. Több olyan közlemény is ismeretes azonban, amely szerint a nyomjelző érfali felvétele nem korrelál az adott betegség aktivitásának megítélésére szolgáló szisztémás gyulladásos laboreltérésekkel vagy a betegség aktivitását leírni hivatott klinikai pontszámokkal. Nem világos, hogy ezekben az esetekben, amikor mérsékelt ${ }^{18} \mathrm{~F}$-FDG-felvétel tapasztalható, ez a larvált érfali gyulladás jele, amelyet csak a PET-vizsgálat képes kimutatni, vagy a lezajlott érfali gyulladás következményeként létrejött vascularis remodelling visszatükröződését látjuk. Az esetleges egyidejü atheroscleroticus laesiók is okozhatnak mérsékelt nyomjelzőfelvételt. E bizonytalanság, valamint különösen a CT-vel kiegészített PET-

1. táblázat |A különböző képalkotó eljárások jellemző eltérései nagyérvasculitisben. A modalitások előnyei és hátrányai ([1-3] felhasználásával)

\begin{tabular}{|c|c|c|c|}
\hline & Jellemző eltérések & A vizsgálat előnyei & A vizsgálat hátrányai \\
\hline $\begin{array}{l}\text { Color duplex } \\
\text { UH-vizsgálat }\end{array}$ & $\begin{array}{l}\text { - Echószegény érfal-megvastagodás } \\
\text { („halo”-jel) } \\
\text { - Közepes echogenitású, nem } \\
\text { atheroscleroticus érfal-megvastagodás } \\
\text { („macaroni”-jel) } \\
\text { - Kompressziós jel } \\
\text { - Beszúkült érszakasz } \\
\text { - Érelzáródás }\end{array}$ & $\begin{array}{l}\text { - Elérhetőség } \\
\text { - Alacsony költség } \\
\text { - Gyors kivitelezés } \\
\text { - Nagy felbontás } \\
\text { - Dianamikus képalkotás } \\
\text { - A sugárexpozíció hiánya }\end{array}$ & $\begin{array}{l}\text { - A vizsgáló személyétől való függés } \\
\text { - A mélyebb struktúrák (mellkasi aorta) } \\
\text { ábrázolásának nehézsége } \\
\text { - A korai érelváltozások kevéssé } \\
\text { észlelhetók }\end{array}$ \\
\hline $\mathrm{CT} / \mathrm{CTA}$ & $\begin{array}{l}\text { - Koncentrikus érfali megvastagodás } \\
\text { - Érfali fokozott halmozás (az artériás } \\
\text { fázisban hypodens, a vénás fázisban } \\
\text { kettős) } \\
\text { - Kalcifikáció (transmuralis) } \\
\text { - Érkörnyezeti ödéma } \\
\text { - Érszúkület, elzáródás, ectasia }\end{array}$ & $\begin{array}{l}\text { - Gyors kivitelezés } \\
\text { - A morfológiai eltérések és a gyulladás } \\
\text { együttesen vizsgálható } \\
\text { - Nagy érterület átfogó ábrázolása } \\
\text { - A kalcifikáció ábrázolása } \\
\text { - Extravascularis struktúrák együttes } \\
\text { vizsgálata }\end{array}$ & $\begin{array}{l}\text { - Költség } \\
\text { - Kisebb felbontás } \\
\text { - Relatíve kis, érátmérő okozta korlát } \\
\text { - Sugárexpozíció } \\
\text { - Potencális nephrotoxicitas }\end{array}$ \\
\hline $\mathrm{MR} / \mathrm{MRA}$ & $\begin{array}{l}\text { - Koncentrikus érfali megvastagodás } \\
\text { - Érfali fokozott halmozás } \\
\text { - Érkörnyezeti ödéma } \\
\text { - Érszúkület, elzáródás, ectasia }\end{array}$ & $\begin{array}{l}\text { - A morfológiai eltérések és a gyulladás } \\
\text { együttesen vizsgálható } \\
\text { - Nagy érterület átfogó ábrázolása } \\
\text { - Érfali ödéma, halmozás ábrázolása } \\
\text { - Nincs sugárexpozíció }\end{array}$ & $\begin{array}{l}\text { - Költség } \\
\text { - Kisebb felbontás } \\
\text { - Hosszabb vizsgálati idő } \\
\text { - Relatíve kis, érátmérő okozta korlát } \\
\text { - A kalcifikáció nem ábrázolódik } \\
\text { - Potenciális nephrotoxicitas }\end{array}$ \\
\hline $\mathrm{PET} / \mathrm{CT}$ & $\begin{array}{l}\text { - Homogén, fokozott 18-FDG-felvétel } \\
\text { az érfalban } \\
\text { - PMR esetén a synoviában is fokozott } \\
\text { nyomjelzőfelvétel }\end{array}$ & $\begin{array}{l}\text { - Funkcionális és morfológiai } \\
\text { információ együttese } \\
\text { - Nagy érterület átfogó ábrázolása } \\
\text { - Korai érkárosodás ábrázolása } \\
\text { - Támogatja a differenciáldiagnózist } \\
\text { (daganatos betegségek, okkult } \\
\text { fertőzés, PMR) }\end{array}$ & $\begin{aligned} \text { - Elérhetőség } \\
\text { - Költség } \\
\text { - A 18-FDG-felvétel az érfalban nem } \\
\text { specifikus } \\
\text { - A vasculitis és az atherosclerosis } \\
\text { elkülönítése nehézségbe ütközhet } \\
\text { - Az érfali struktúra nem ítélhető meg } \\
\text { - Magas sugárexpozíció }\end{aligned}$ \\
\hline
\end{tabular}

18-FDG $={ }^{18}$ F-fluor-dezoxi-glükóz; CT = számítógépes tomográfia; CTA = CT-angiográfia; $\mathrm{MR}=$ mágneses rezonancia; $\mathrm{MRA}=$ mágnesesrezonancia-angiográfia; $\mathrm{PET}=$ pozitronemissziós tomográfia; $\mathrm{PMR}=$ polymyalgia rheumatica; $\mathrm{UH}=\mathrm{ultrahang}$ 
vizsgálat sugárterhelése és a felmerülő költségtényezők miatt a nagyérvasculitis monitorozására ezt az eljárást jelenleg nem alkalmazzák.

\section{Képalkotó vizsgálatok a nagyérvasculitisek prognózisának megítélésében}

130, nagyérvasculitisben szenvedő beteg 5 éves utánkövetése során a megfigyelési időszak elején végzett PET/ CT vizsgálat pozitivitása összefüggést mutatott a 33 (medián) hónapos utánkövetés során kialakult aortamegbetegedéssel (dissectio, aneurizma kialakulása) [44]. Egy másik vizsgálatban a PET-vizsgálat során kimutatott érfali nyomjelző intenzitása és az eltérés kiterjedtsége összefüggést mutatott a későbbiekben bekövetkező érszövődmények előfordulásával, valamint a terápia hatástalanságával [45]. Kis esetszámú vizsgálat hívta fel a figyelmet arra, hogy Takayasu-arteritisben a glükóz- és a nátrium-fluorid-tartalmú nyomjelző felvétele különbözik egymástól. Az valószínúsíthető, hogy a két nyomjelző felvétele a betegség különböző stádiumaiban különböző mértékű. Ilyen értelemben a nátrium-fluorid-tartalmú nyomjelző intenzitása a betegség előrehaladtával jellemző kalcifikációt tükrözheti vissza, aminek prognosztikai jelentősége lehet [46].

\section{Az Európai Reumaellenes Liga (EULAR) ajánlása a képalkotó eljárások alkalmazására nagyérvasculitisben}

A fentiekben részletezett képalkotó eljárások látványos fejlődése, a különböző modalitások alkalmazhatósága a nagyérvasculitisek diagnosztikájában, illetve azok kiterjedtségének és aktivitásának megítélésében, valamint a prognózisbecslésben vezetett az Európai Reumaellenes Liga (EULAR) által jegyzett, a klinikai gyakorlat számára készült ajánlás megjelenéséhez. Ebben 12 pontban foglalták össze azokat a javaslatokat, amelyek nagyérvasculitisben a képalkotó eljárások alkalmazásának feltételeit, szempontjait fogalmazzák meg [14]. Az ajánlásokból kirajzolódik, hogy nagyérvasculitisek gyanúja esetén a mihamarabbi képalkotó vizsgálat elvégzése ajánlott. Az óriássejtes arteritis cranialis formája esetén UH- (esetleg MR-) vizsgálat, extracranialis nagyér-manifesztáció vagy Takayasu-arteritis esetén mindegyik képalkotó modalitás ajánlható az egyes módszerek előnyeinek és hátrányainak mérlegelése mellett. Az utóbbi szempontokat az 1. táblázat foglalja össze. A képalkotó vizsgálat eredményének értékelésekor alapvető a klinikai gyanú megalapozottságának mérlegelése. E két tényező együttese segíthet abban, hogy alacsony gyanú és negatív képalkotó eredmény esetén a diagnózist kizártnak tekintsük, vagy ellenkezőleg, impresszív klinikai kép esetén akár további képalkotó vagy adott esetben szövettani vizsgálat kivitelezésére törekedjünk. Sajnos más betegségekkel ellentétben a nagy- érvasculitis esetére kidolgozott, a kockázatbecslést (preteszt-valószínúség) segítő pontszámrendszer nem áll rendelkezésre. A betegség fellángolásának gyanúja esetén, amikor a gyulladásos laboreltérések értékelése nem egyértelmű, képalkotó eljárás kezdeményezését javasolják. Az ajánlásban az az elem is megjelenik, hogy a képalkotó vizsgálatok közötti választást befolyásolja az adott eszköz elérhetősége, a vizsgálat kivitelezéséhez és értékeléséhez szükséges szakértelem megléte [14].

Az EULAR-ajánlásban foglaltak segíthetik az alkalmazás optimalizációját, fontos azonban jelezni, hogy ezek az ajánlások elsősorban szakértői véleményeken alapulnak, és nagyon kevés az olyan, magas evidenciaszintü tanulmány, amely az adott kérdést megnyugtatóan lezárná. Számos további probléma vethető fel (az adott képalkotó eljárással leírt eltérések prognosztikai értéke, az érfali gyulladás nyomon követése, a képalkotó vizsgálatok kivitelezésének és értékelésének standardizációja, a szúrés mikéntjének pontosabb megfogalmazása, a terápia hatékonyságának megítélése), amelyek további, gondosan tervezett klinikai vizsgálatok tárgyai lehetnek.

\section{Következtetés}

Az utóbbi években a technológiai fejlődésnek köszönhetően a különböző képalkotó eljárások a nagyérvasculitisek vizsgálatának szerves részévé váltak. Kirajzolódni látszik, hogy a radiológiai eljárásoktól nem kizárólag a diagnózis felállításakor várhatunk segítséget. A betegség kiterjedtsége, az érfali aktivitás, valamint a prognózist meghatározó késői érelváltozások is elemezhetővé válnak. Magyarországon a nagyérvasculitisek képalkotó diagnosztikájával kapcsolatosan kevés a tapasztalat. Ez nem kizárólag a betegség ritka voltával, az ebben jártas szakemberek hiányával, az alkalmas technikai eszközök korlátozott elérhetőségével magyarázható. Szükséges volna a környező országokhoz hasonlóan a finanszírozás módosítása is, amely ebben a körben (nagyérvasculitisek) Magyarországon jelenleg nem teszi lehetővé egyes modalitások (PET-vizsgálatok) alkalmazását a biztosító által támogatott módon. A jelen összefoglaló a nagyérvasculitisek képalkotó vizsgálatairól alkotott ismeretek bővítését tüzte ki célul, annak reményében, hogy hazánkban az érintett betegpopuláció felismerése és gondozása mindinkább sikeressé fog válni.

Anyagi támogatás: A közlemény megírása anyagi támogatásban nem részesült.

Szerzôi munkamegosztás: K. E.: Részvétel a háttérirodalom összegyüjtésében, a tanulmány végleges formájának kialakításában és összeállításában. B. Gy., D. E., M. M.: Az egyes képalkotó modalitásokkal kapcsolatos szövegrészek kritikai olvasata, szakmai véleményezése, stiliszti- 
kai korrekció. J. Z., F. K.: Az összefoglaló kritikai olvasata, stilisztikai korrekció. A cikk végleges változatát valamennyi szerző elolvasta és jóváhagyta.

Érdekeltségek: A szerzőknek nincsenek érdekeltségeik.

\section{Köszönetnyilvánítás}

Köszönetet mondunk $d r$. Subai Ferencnek, aki az MR-vizsgálat illusztrációjának szánt ábra elkészítésében segített.

\section{Irodalom}

[1] Jennette JC, Falk RJ, Bacon PA, et al. 2012 revised International Chapel Hill Consensus Conference Nomenclature of Vasculitides. Arthritis Rheum. 2013; 65: 1-11.

[2] Prieto-Gonzalez S, Espigol-Frigole G, Garcia-Martinez A, et al. The expanding role of imaging in systemic vasculitis. Rheum Dis Clin North Am. 2016; 42: 733-751.

[3] Keser G, Aksu K. Diagnosis and differential diagnosis of largevessel vasculitides. Rheumatol Int. 2019; 39: 169-185.

[4] Berger CT, Sommer G, Aschwanden M, et al. The clinical benefit of imaging in the diagnosis and treatment of giant cell arteri tis. Swiss Medical Wkly. 2018; 148: w14661.

[5] Guggenberger K, Bley T. Imaging in large vessel vasculitides. Rofo 2019; 191: 1083-1090.

[6] Hunder GG, Bloch DA, Michel BA, et al. The American College of Rheumatology 1990 criteria for the classification of giant cell arteritis. Arthritis Rheum. 1990; 33: 1122-1128.

[7] Arend WP, Michel BA, Bloch DA, et al. The American College of Rheumatology 1990 criteria for the classification of Takayasu arteritis. Arthritis Rheum. 1990; 33: 1129-1134.

[8] Seeliger B, Sznajd J, Robson JC, et al. Are the 1990 American College of Rheumatology vasculitis classification criteria still valid? Rheumatology (Oxford) 2017; 56: 1154-1161.

[9] Dejaco C, Duftner C, Buttgereit F, et al. The spectrum of giant cell arteritis and polymyalgia rheumatica: revisiting the concept of the disease. Rheumatology (Oxford) 2017; 56: 506-515.

[10] Muratore F, Kermani TA, Crowson CS, et al. Large-vessel dilatation in giant cell arteritis: a different subset of disease? Arthritis Care Res (Hoboken). 2018; 70: 1406-1411.

[11] Martinez-Taboada VM, Alvarez L, RuizSoto M, et al. Giant cell arteritis and polymyalgia rheumatica: role of cytokines in the pathogenesis and implications for treatment. Cytokine 2008; 44: 207-220.

[12] Zhu FP, Luo S, Wang ZJ, et al. Takayasu arteritis: imaging spectrum at multidetector CT angiography. Br J Radiol. 2012;85 el282-el292.

[13] University of Oxford, Medical Sciences Division, Nuffield Department of Orthopaedics, Rheumatology and Musculoskeletal Sciences. Diagnostic and Classification Criteria in Vasculitis Study (DCVAS). NDORMS, Oxford, 2017. Available from: https://research.ndorms.ox.ac.uk/public/dcvas/index.php [accessed: February 20, 2020].

[14] Dejaco C, Ramiro S, Duftner C, et al. EULAR recommendations for the use of imaging in large vessel vasculitis in clinical practice. Ann Rheum Dis. 2018; 77: 636-643.

[15] Schmidt WA, Kraft HE, Völker L, et al. Colour Doppler sonography to diagnose temporal arteritis. Lancet 1995; 345: 866

[16] Schmidt WA. Ultrasound in the diagnosis and management of giant cell arteritis. Rheumatology (Oxford) 2018; 57(Suppl 2): ii22-ii31.

[17] Monti S, Floris A, Ponte C, et al. The use of ultrasound to assess giant cell arteritis: review of the current evidence and practical guide for the rheumatologist. Rheumatology (Oxford) 2018; 57: 227-235.
[18] Aschwanden M, Daikeler T, Kesten F, et al. Temporal artery compression sign - a novel ultrasound finding for the diagnosis of giant cell arteritis. Ultraschall Med. 2013; 34: 47-50.

[19] Schäfer VS, Juche A, Ramiro S, et al. Ultrasound cut-off values for intima-media thickness of temporal, facial and axillary arteries in giant cell arteritis. Rheumatology (Oxford) 2017; 56: 14791483. [Correction: Rheumatology (Oxford) 2017; 56: 1632.]

[20] Czihal M, Lottspeich C, Hoffmann U. Ultrasound imaging in the diagnosis of large vessel vasculitis. VASA 2017; 46: 241-253.

[21] Luqmani R, Lee E, Singh S, et al. The role of ultrasound compared to biopsy of temporal arteries in the diagnosis and treatment of giant cell arteritis (TABUL): a diagnostic accuracy and cost-effectiveness study. Health Technol Assess. 2016; 20: $1-238$.

[22] Muratore F, Pipitone N, Salvarani C, et al. Imaging of vasculitis: state of the art. Best Pract Res Clin Rheumatol. 2016; 30: 688706.

[23] Holm PW, Sandovici M, Slart RH, et al. Vessel involvement in giant cell arteritis: an imaging approach. J Cardiovasc Surg (Torino). 2016; 57: 127-136.

[24] Kolossváry E, Kollár A, Pintér H, et al. Bilateral axillobrachial and external carotid artery manifestation of giant cell arteritis: important role of color duplex ultrasonography in the diagnosis. Int Angiol. 2005; 24: 202-205.

[25] Monti S, Águeda AF, Luqmani RA, et al. Systematic literature review informing the 2018 update of the EULAR recommendation for the management of large vessel vasculitis: focus on giant cell arteritis. RMD Open 2019; 5: e001003.

[26] Kim SY, Park JH, Chung JW, et al. Follow-up CT evaluation of the mural changes in active Takayasu arteritis. Korean J Radiol. 2007; 8: 286-294.

[27] Duftner C, Dejaco C, Sepriano A, et al. Imaging in diagnosis, outcome prediction and monitoring of large vessel vasculitis: a systematic literature review and meta-analysis informing the EULAR recommendations. RMD Open 2018; 4: e000612.

[28] Bley TA, Uhl M, Carew J, et al. Diagnostic value of high-resolution MR imaging in giant cell arteritis. AJNR Am J Neuroradiol. 2007; 28: 1722-1727.

[29] Guggenberger KV, Bley TA. Magnetic resonance imaging and magnetic resonance angiography in large-vessel vasculitides. Clin Exp Rheumatol. 2018; 36(Suppl 114): 103-107.

[30] Barra L, Kanji T, Malette J, et al. Imaging modalities for the diagnosis and disease activity assessment of Takayasu's arteritis: a systematic review and meta-analysis. Autoimmun Rev. 2018; 17: 175-187.

[31] Rosenblum JS, Quinn KA, Rimland CA, et al. Clinical factors associated with time-specific distribution of $18 \mathrm{~F}$-fluorodeoxyglucose in large-vessel vasculitis. Sci Rep. 2019; 9: 15180.

[32] Jiemy WF, Heeringa P, Kamps JA, et al. Positron emission tomography (PET) and single photon emission computed tomography (SPECT) imaging of macrophages in large vessel vasculitis: Current status and future prospects. Autoimmun Rev. 2018; 17: 715-726.

[33] Slart RH, et al. FDG-PET/CT(A) imaging in large vessel vasculitis and polymyalgia rheumatica: joint procedural recommendation of the EANM, SNMMI, and the PET Interest Group (PIG), and endorsed by the ASNC. Eur J Nucl Med Mol Imaging 2018; 45: 1250-1269.

[34] Koster MJ, Matteson EL, Warrington KJ. Large-vessel giant cell arteritis: diagnosis, monitoring and management. Rheumatology (Oxford) 2018; 57(Suppl 2): ii32-ii42.

[35] Padoan R, Crimì F, Felicetti M, et al. Fully integrated 18F-FDG $\mathrm{PET} / \mathrm{MR}$ in large vessel vasculitis. Q J Nucl Med Mol Imaging 2019 Oct 9. Doi: 10.23736/S1824-4785.19.03184-4. [Epub ahead of print]

[36] Sreih AG, Alibaz-Oner F, Kermani TA, et al. Development of a core set of outcome measures for large-vessel vasculitis: report from OMERACT 2016. J Rheumatol. 2017; 44: 1933-1937. 
[37] Nakagomi D, Cousins C, Sznajd J, et al. Development of a score for assessment of radiologic damage in large-vessel vasculitis (combined arteritis damage score, CARDS). Clin Exp Rheumatol. 2017; 35(Suppl 103): 139-145.

[38] Tombetti E, Godi C, Ambrosi A, et al. Novel angiographic scores for evaluation of large vessel vasculitis. Sci Rep. 2018; 8: 15979.

[39] Soriano A, Pazzola G, Boiardi L, et al. Distribution patterns of 18F-fluorodeoxyglucose in large vessels of Takayasu's and giant cell arteritis using positron emission tomography. Clin Exp Rheumatol. 2018; 36(Suppl 111): 99-106.

[40] Germano G, Macchioni P, Possemato N, et al. Contrast-enhanced ultrasound of the carotid artery in patients with large vessel vasculitis: correlation with positron emission tomography findings. Arthritis Care Res (Hoboken). 2017; 69: 143-149.

[41] Sinha D, Mondal S, Nag A, et al. Development of a colour Doppler ultrasound scoring system in patients of Takayasu's arteritis and its correlation with clinical activity score (ITAS 2010). Rheumatology (Oxford) 2013; 52: 2196-2202.

[42] Papa M, De Cobelli F, Baldissera E, et al. Takayasu arteritis: intravascular contrast medium for MR angiography in the evaluation of disease activity. Am J Roentgenol. 2012; 198: W279W284.
[43] Spira D, Xenitidis T, Henes J, et al. MRI parametric monitoring of biological therapies in primary large vessel vasculitides: a pilot study. Br J Radiol. 2016; 89: 20150892.

[44] de Boysson H, Liozon E, Lambert M, et al. 18F-fluorodeoxyglucose positron emission tomography and the risk of subsequent aortic complications in giant-cell arteritis: a multicenter cohort of 130 patients. Medicine (Baltimore) 2016; 95: e3851.

[45] Dellavedova L, Carletto M, Faggioli P, et al. The prognostic value of baseline ${ }^{18} \mathrm{~F}$-FDG PET/CT in steroid-naïve large-vessel vasculitis: introduction of volume-based parameters. Eur J Nucl Med Mol Imaging 2016; 43: 340-348.

[46] Alexanderson-Rosas E, Monroy-Gonzalez AG, Juarez-Orozco $\mathrm{LE}$, et al. $\left[{ }^{18} \mathrm{~F}\right]$-Sodium fluoride uptake in Takayasu arteritis. J Nucl Cardiol. 2017; 24: 1674-1679.

(Kolossváry Endre dr., Budapest, Tétényi út 12-16., 1115 e-mail: kolossendre@gmail.com)

\section{"Numquam ubi diu fuit ignis defecit vapor." (Hosszas tüznek mindig megmarad a füstje.)}

A cikk a Creative Commons Attribution 4.0 International License (https://creativecommons.org/licenses/by/4.0/) feltételei szerint publikált Open Access közlemény, melynek szellemében a cikk bármilyen médiumban szabadon felhasználható, megosztható és újraközölhetö, feltéve, hogy az eredeti szerző és a közlés helye, illetve a CC License linkje és az esetlegesen végrehajtott módositások feltüntetésre kerülnek. (SID_1) 